\title{
Population dynamics of tundra voles in relation to configuration of willow thickets in southern arctic tundra
}

\author{
John-André Henden · Rolf Anker Ims • \\ Nigel Gilles Yoccoz $\cdot$ Raymond Sørensen • \\ Siw Turid Killengreen
}

Received: 30 August 2010 / Revised: 12 October 2010 / Accepted: 14 October 2010 / Published online: 4 November 2010

(C) The Author(s) 2010. This article is published with open access at Springerlink.com

\begin{abstract}
The areal extent and configuration of thickets of willow shrubs are currently changing in the Arctic both as an effect of global warming and changed browsing pressure of reindeer. These changes have been predicted to impact the distribution and abundance of wildlife species relying on willow thickets as habitat. We assessed the relation between variables quantifying willow thicket configuration and population dynamics of tundra voles (Microtus oeconomus) in three riparian regions in Finnmark, northern Norway, which were subject to intense browsing by semidomesticated reindeer. The tundra vole, which exhibits 5 -year population cycles in Finnmark, is the dominant small rodent species in riparian landscape elements in southern arctic tundra. In the course of a 4-year trapping study, tundra vole populations went through the cyclic phases of increase, peak and crash, however, with distinct differences between the three regions in the population dynamics. Within regions, the occupancy pattern during the increase phase was positively related to willow thicket configuration (in particular edge density and willow height) only in the region attaining the highest abundance and occupancy. However, local abundance was not clearly related to habitat
\end{abstract}

Electronic supplementary material The online version of this article (doi:10.1007/s00300-010-0908-7) contains supplementary material, which is available to authorized users.

J.-A. Henden $(\varangle) \cdot$ R. A. Ims · N. G. Yoccoz · R. Sørensen ·

S. T. Killengreen

Department of Arctic and Marine Biology,

University of Troms $\varnothing, 9037$ Troms $\varnothing$, Norway

e-mail: john-andre.henden@uit.no

Present Address:

R. Sørensen

Norwegian Wild Reindeer Centre North, 2661 Hjerkinn, Norway features within any regions. The lack of consistency in the response of tundra vole populations to willow thicket configuration, as well as the positive relation between the degree of thicket shredding and tundra vole habitat occupancy in one of the regions, indicates that tundra voles will not be much affected by climate or browsing induced changes in the shrubbiness of the tundra in the future.

Keywords Over-browsing $\cdot$ Shrub expansion . Fragmentation $\cdot$ Abundance $\cdot$ Occupancy ·

Large-scale study

\section{Introduction}

Willow shrubs (Salix spp) forming thickets are conspicuous structural elements in southern arctic tundra, where they serve important ecological functions including habitat for wildlife (Bliss et al. 1973; Bliss 1997). There has been a recent surge of studies focusing on the dynamics of willow thickets in the Arctic. There are two main reasons for this. On one hand, an increased extent of willow thickets has been observed in parts of the arctic and this has been attributed to a warming climate (Sturm et al. 2001; Chapin et al. 2005; Tape et al. 2006). On the other hand, where herds of semi-domesticated reindeer (Rangifer tarandus) have increased substantially over the last decades, such as in Finnmark in northern Fennoscandia (Moen and Danell 2003; Tveraa et al. 2007) and in Yamal in western Siberia (Forbes et al. 2009), studies have shown that reindeer browsing may reduce the willow thickets (Olofsson 2001; Pajunen et al. 2008; Olofsson et al. 2009; Kitti et al. 2009). The effect of such changes in areal extent and height of willow thickets in tundra has begun to be explored in terms of their functions in local and global energy balance (Sturm 
et al. 2005; Chapin et al. 2005). As yet, however, there have been no studies that have explicitly analyzed the effects of such changes on arctic wildlife populations using willow thickets as habitat, although such effects have been predicted (den Herder et al. 2004; Bråthen et al. 2007; Ims et al. 2007; den Herder et al. 2008; Forbes et al. 2009). Here, we provide such an analysis focusing on tundra voles (Microtus oeconomus).

Small rodents are key herbivores in tundra ecosystems (Batzli et al. 1980). In landscape elements with willow thickets, such as moist and nutrient rich sediment plains along creeks and rivers, the tundra vole is often the dominant small rodent species both in arctic America (Batzli and Henttonen 1990; Tast 1966) and Europe (Tast 1966). These riparian habitats provide tundra voles with food plants such as herbs and graminoids, while the willow thickets most likely serve the function as cover and protection against avian (Tast 1968) and some mammalian predators. The importance of tall and dense vegetation cover for tundra voles has been well demonstrated through a series of smallscale model system experiments conducted on enclosed plots in temperate agricultural farmland (e.g. Ims et al. 1993; Andreassen et al. 1998). However, while tundra voles typically reside most of the time under the protective canopy of tall vegetation, they tend to forage along the edge toward open habitat providing more nutritious food plants (Hovland et al. 1999). The different functions of open habitats providing food and closed habitat providing cover can result in non-linear, context-dependent habitat selection functions (c.f. Mysterud and Ims 1998) and ultimately account for some counter-intuitive population responses in tundra voles to experimental habitat fragmentation. For instance, experimental shredding (Meffe and Carroll 1994) and fragmentation of habitat in previous model system studies have shown that higher tundra vole abundances may be attained in more shredded and fragmented habitats (e.g. Ims et al. 1993; Hovland et al. 1999; Johannesen et al. 2003). Moreover, these previous studies have also demonstrated how large-scale factors, in particular those determining regional predation pressure, can entirely overrule the impact of local habitat fragmentation (Ims and Andreassen 2000).

With the insight from these previous relatively smallscale and short-term experimental studies in mind, we analyze local and regional scale dynamics of natural tundra vole populations during the phases of increase, peak and crash of a typical population cycle. The study was conducted in three riparian regions in north Norwegian tundra landscapes, where willow thickets exhibited variable areal extents and fragmentation. This study setting allowed us to assess the effects of willow thicket configuration variables that are likely to be affected both by reindeer browsing and climate change.

\section{Methods}

Study area

The study was carried out during the years 2005-2008 in three riparian regions in northeastern Finnmark, northern Norway. Two of the regions were situated at the Varanger peninsula $\left(70-71^{\circ} \mathrm{N}\right.$ and $\left.28-31^{\circ} \mathrm{E}\right)$, while the third was at Ifjordfjellet $\left(71^{\circ} \mathrm{N}, 27^{\circ} \mathrm{E}\right)$ about $100 \mathrm{~km}$ west of Varanger peninsula (Fig. 1). The two study regions at Varanger peninsula were along the main river valleys of Vestre Jakobselv (VJ) and Komagdalen (KO), whereas in the region Ifjordfjellet (IF), several smaller rivers and creeks, mostly tributaries to the river Storelva, were included. The study regions are classified as erect low-shrub tundra belonging to the southern arctic zone in the north and east of Varanger peninsula (Walker et al. 2005) and sub-arctic mountain tundra in the south and west of Varanger peninsula and Ifjordfjellet (Moen 1999). The vegetation characteristics are grossly similar among the study regions (Killengreen et al. 2007). Heaths mainly composed of dwarf shrubs such as Empetrum hermaphroditum, Betula nana and Vaccinium spp., dominate the landscape (Oksanen and Virtanen 1995; Killengreen et al. 2007; Ims et al. 2007). In heath habitats, graysided voles (Myodes rufucanus) dominate numerically among the small rodent species (Oksanen and Oksanen 1981; Ekerholm et al. 2001), while Norwegian lemming (Lemmus lemmus) may be found in high numbers in the outbreak years which in Finnmark occur irregularly (Oksanen et al. 2008). Tundra voles prefer spatially much more restricted elements of the tundra landscape (Oksanen and Oksanen 1981), in particular moist depressions on sediment plains along creeks and rivers. In these riparian areas, the vegetation is substantially lusher than the surrounding landscape with meadows dominated by graminoids and herbs interspersed with patches of willow thickets (Ravolainen 2009). The edges between the meadows and the thickets are usually sharp (Figs. 1 and 2). While the two study regions at Varanger peninsula (i.e. KO and VJ) constitute summer pastures for more than 10,000 reindeer and are thus subject to intense grazing, the region IF is mainly a transition area for reindeer herds in spring and autumn and is thus subject to less grazing. Vole populations in Finnmark normally exhibit a synchronous 5-year cycle and the latest peak before the present study commenced was in 2002 (Yoccoz and Ims 2004; Killengreen et al. 2007; Oksanen et al. 2008).

\section{Study design}

This study was designed to assess the effect of configuration of willow thickets in riparian landscape elements. For this purpose, we strategically selected study units to span the existing variation in the areal extent and degree of 


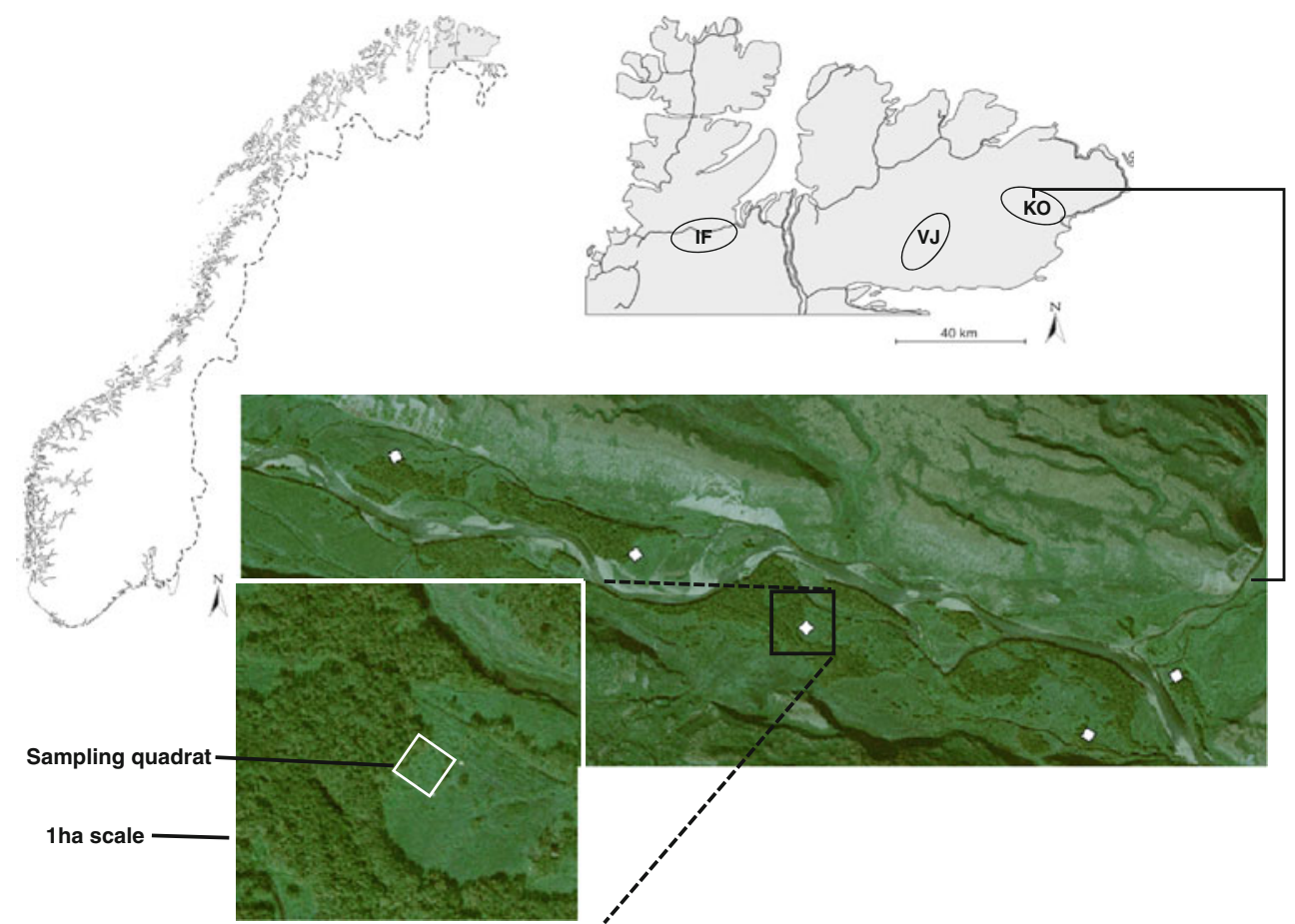

Fig. 1 Map giving the location of the three study regions (IF Ifjordfjellet, $V J$ Vestre Jakobselv and $K O$ Komagdalen) in eastern Finnmark, northeastern Norway and an aerial photograph showing the distribution of willow thickets and the location of 5 sampling quadrats (white

fragmentation of willow thickets within each of the study regions. All study units were situated on mineral soils where the willow thickets are imbedded in lush meadow vegetation. The study units were $15 \times 15$ meter square plots hereafter referred to as sampling quadrats. To further standardize the selection of sampling quadrats, it was required that they should not have more than $30 \%$ mires or be flooded. Each sampling quadrat was placed so that one side of the quadrat was lining the edge of the thicket, while the quadrat extended into the surrounding meadow (Fig. 1). The distance between two adjacent sampling quadrats was at least 164 meters, and the average distance to the nearest quadrat was 652 meters ( $\mathrm{SD}=524$ meters). We placed 12 sampling quadrats in each of the regions $\mathrm{KO}$ and IF, while there were 13 sampling quadrats in region VJ (i.e. in total $N=37$ sampling quadrats).

Small rodent population census

Small rodent populations were censused in all sampling quadrats according to the small quadrat method of Myllymãki et al. (1971). According to this method, 3 snap traps baited with raisins and rolled oat were selectively set (e.g. on vole runways or in front of tunnels) within a radius of 2 meters from each corner of the sampling quadrat (i.e. 12 traps per quadrat). There were two trapping periods per year (2005-2008), one in summer (mid July) and one in squares) in study region KO. The enlarged square of the photograph highlights the measurement scale $(1$ ha scale) of $100 \times 100$ meter for the area-based willow thicket variables

autumn (early September). Each trapping period extended two trap nights and traps where checked daily, i.e. two checks, one every $24 \mathrm{~h}$. The short-term trapping effort, the small spatial extent of each of the small quadrats as well as their scattered distribution within each of the regions makes it reasonable to assume that the removal trapping had negligible effect on the tundra vole population dynamics (Myllymãki et al. 1971).

Quantifying willow thicket configuration

The areal extent and degree of fragmentation of willow thicket size were derived from aerial photographs taken in the summer of 2006. The photos were ortho-rectified in raster tiff-format and had a ground resolution of 0.20 meter. For converting the photographs from .tiff to .imgformat, we used ARC GIS-software, version 9.1 (Environmental Systems Research Institute 2002). All willow thickets within the different regions were digitized in GRASS, version 6.1 (Grass Development Team 2006). The appropriate raw data files were imported in FRAGSTAT, version 3.3 (McGarigal and Marks 1995). FRAGSTAT was used to obtain area-based variables quantifying the areal extent and degree of fragmentation of the willow thickets within a $100 \times 100$ meter square (i.e. 1 ha) centered on each of the sampling quadrats. The areal extent of willow thickets was quantified as the 


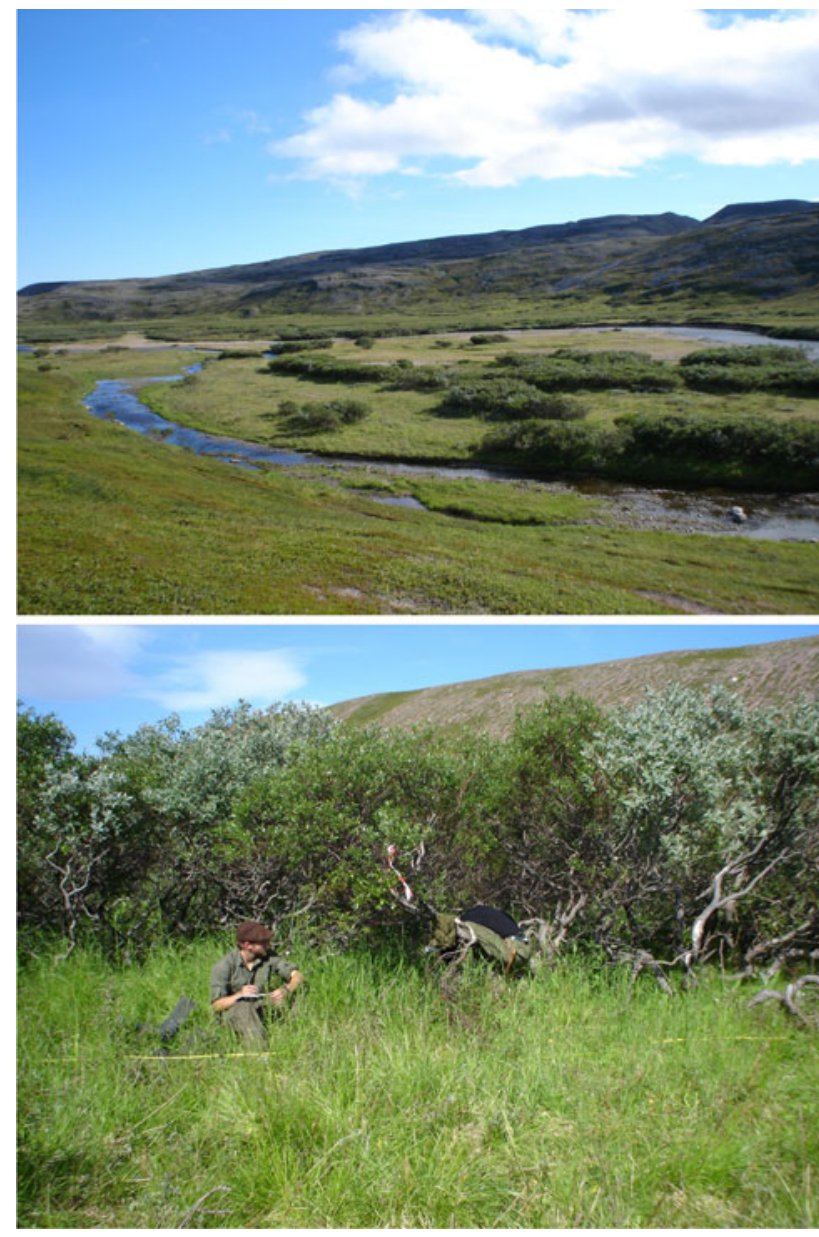

Fig. 2 Upper panel shows one example of the area-based configuration of willow thickets around one sampling quadrate in study site $\mathrm{KO}$. Lower panel shows one example of the vertical configuration of willow thickets in one sampling quadrate in study site $\mathrm{KO}$

percent cover of thickets. To describe the degree of fragmentation of willow thickets, we used two variables that are straightforward to interpret in terms of biological significance for small mammals. These were patch density (number of patches per ha) and edge density (meters of edge per ha). Increasing values for both of these variables indicate increased shredding or fragmentation of thickets. For all analyses, we defined a willow patch as consisting of an aggregation of pixels that were spatially connected using the eight neighbors rule (McGarigal and Marks 1995).

As reindeer browsing has been shown to also affect the vertical structure of willow thickets (den Herder et al. 2004; Kitti et al. 2009; Pajunen et al. 2008) and climate warming affects the vertical growth of willow shoots (Forbes et al. 2010), we measured the height and density of the thickets in the field. These two variables were measured at four points along the side of the sampling quadrat lining the thicket. Willow density was assessed by point frequency, placing a telescopic stick vertically 1 meter inside the thicket and counting the number of hits with secondary stems and branches. Willow height was measured as the highest willow branch inside a circle with $20 \mathrm{~cm}$ radius surrounding the telescopic stick. The sampling quadrat score for the willow height and density variables was taken as the mean of the four measurements.

The measurement scale ( $1 \mathrm{ha}$ ) for the three area-based thicket variables was chosen as it gave non-overlapping measurements and corresponded to the trapping grid size used in many studies of Microtus species (Stenseth and Lidicker 1992). However, to evaluate whether the choice of measurement scale mattered, we also quantified the same variables within a $200 \times 200$ meter square. Measurements were strongly correlated (Pearson correlation >0.8) between the two scales indicating that our choice of measurement scale did not influence the results. Further, exploratory analyses of the willow thicket fragmentation variables showed, however, that patch density and edge density were strongly correlated (Pearson correlation = 0.72). Thus, we chose to only include one of them in the statistical modeling of tundra vole population dynamics. We included edge density because of the preference by tundra voles for edge habitat demonstrated in previous studies (Hovland et al. 1999). None of the other thicket variables was strongly correlated. Moreover, although the mean of the thicket variables differed somewhat between the three study regions, their ranges were highly overlapping (Table 1), meaning that regional effects could be statistically separated from the effect of willow thicket variables.

Table 1 Mean and range of the selected willow thicket configuration variables at the $100 \times 100 \mathrm{~m}$ (1 ha) scale

\begin{tabular}{|c|c|c|c|c|c|c|c|c|c|}
\hline \multirow[t]{2}{*}{ Variables } & \multirow[t]{2}{*}{ Measure } & \multicolumn{2}{|c|}{ All regions } & \multicolumn{2}{|l|}{ Ifjord } & \multicolumn{2}{|c|}{ Komagdalen } & \multicolumn{2}{|c|}{ V. Jakobselv } \\
\hline & & Mean & Range & Mean & Range & Mean & Range & Mean & Range \\
\hline Willow cover & $\%$ & 27.06 & {$[5.41,58.89]$} & 31.15 & {$[6.01,58.89]$} & 24.09 & {$[7.33,57.40]$} & 26.01 & {$[5.41,46.19]$} \\
\hline Edge density & $\mathrm{m}$ & 661.68 & {$[250.90,1,839.29]$} & 824.70 & {$[401.61,1,839.29]$} & 520.75 & {$[250.90,965.07]$} & 641.29 & {$[263.33,1,290.78]$} \\
\hline Willow height & $\mathrm{cm}$ & 160.68 & {$[77.50,270.00]$} & 117.30 & {$[77.50,220.00]$} & 210.63 & {$[145.00,270.00]$} & 154.62 & {$[110.00,220.00]$} \\
\hline Willow density & no. of hits & 2.50 & {$[0.25,5.50]$} & 2.71 & {$[2.00,3.25]$} & 2.58 & {$[0.75,5.50]$} & 2.04 & {$[0.25,4.25]$} \\
\hline
\end{tabular}


Statistical analyses

We focused on two aspects of tundra vole population dynamics that could be affected by willow thicket variables. First, we highlighted the colonization of habitat during the increase phase of the cycle by analyzing the patterns of occupancy in the 2 years (2005 and 2006) tundra vole populations were increasing in all study regions. Second, local abundance variation among the sampling quadrats was analyzed including the entire sampling period. In the first case (i.e. occupancy during colonization), generalized linear mixed-effects models (GLMMs) were applied to a binary response variable (presence or absence of tundra voles in the sampling quadrats per 2 trap nights) with a logit link function and a binomial distribution. In the second case, abundance variation was analyzed with linear mixed-effects models (LMMs) applied to log transformed number of tundra voles $(\log [N+1])$ captured per quadrat. Fixed effect in both classes of models was the four willow configuration variables, year (2005-2006 in the occupancy models and 2005-2008 in the abundance models), season (summer and autumn) and region (VJ, KO and IF). Sampling quadrat identity was specified as random effects (Pinheiro and Bates 2000). Willow configuration variables were standardized (i.e. scaled with Mean $=0$ and $\mathrm{SD}=1$ ) to ease comparison of their effects. Both GLMMs and LMMs were fitted using the lme4 package (Bates et al. 2008) in the software R (R Development Core Team 2009).

Model selection started from a model containing all twoway interactions between the continuous willow variables and categorical variables year, region and season as well as the twoway interactions region*year and region*season to account for different dynamics between the regions (Table S1 \& S2, Appendix). From this model, we formed four candidate models (c.f. Burnham and Anderson 2002) by removing sets of twoway interactions, sequentially (see Table S1 \& S2, Appendix). Log-likelihood ratio tests (LRT) were used to compare candidate models and to subsequently identify the final best model (Table S1 \& S2 Appendix). Following Pinheiro and Bates (2000), maximum likelihood (ML)-fitted LMM's was used when models were compared to each other; whereas restricted maximum likelihood (REML)-fitted LMM's was used for parameter estimation. GLMM's was fitted using the Laplace approximation (Bates et al. 2008). Models were checked for constant variance of the residuals and presence of outliers and approximate normality of the predicted random effects.

\section{Results}

Regional population dynamics

During the 4 years of the study, a total of 624 small rodents were caught; of which, 431 (69\%) were tundra voles, 101
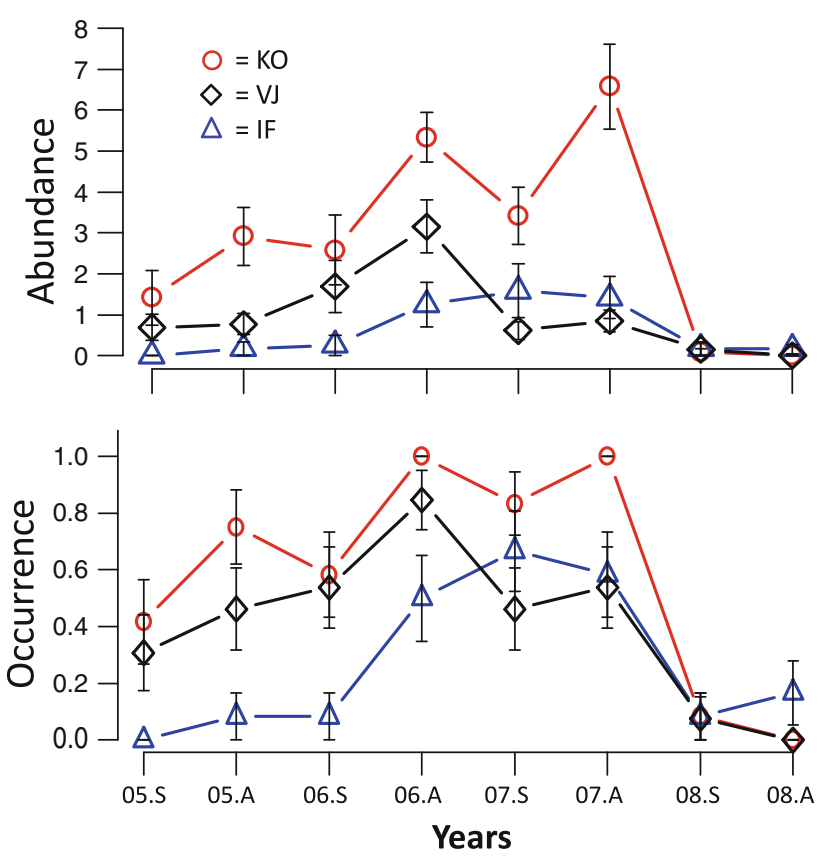

Fig. 3 Seasonal and multi-annual dynamics in local abundance (number of tundra voles caught per sampling quadrat, upper panel) and occupancy (proportion of sampling quadrats with at least one tundra vole caught per 2 trap nights, lower panel) of tundra voles in the three study regions. All estimates are seasonal ( $S$ Summer, $A$ Autumn) mean values with standard error limits. Note that the equivalent "number per 100 trap nights" metric of the highest $(07 . \mathrm{A}=6.58)$ and lowest $(08 . \mathrm{S}=0.08)$ abundance in $\mathrm{KO}$ (upper panel) is 27.43 and 0.35 , respectively

(16\%) were Norwegian lemmings and $92(15 \%)$ were graysided voles. Of the tundra voles, $103(24 \%)$ was caught in VJ, $268(62 \%)$ in $\mathrm{KO}$ and 60 (14\%) at IF. The tundra vole populations in all three study regions were in the increase phase of the population cycle from the onset of the study in summer 2005 until autumn 2006, and all populations had crashed to similar low levels of abundance and occupancy by summer 2008 (Fig. 3). However, besides these two common features of the regional population dynamics, the three regions differed substantially in their mean levels of abundance and occupancy as well as their timing of population peaks and onset of the crash. KO had clearly the highest abundance and occupancy of the three regions. In this region, almost $100 \%$ occupancy was attained in autumn 2006, whereas the abundance continued to increase and peaked in autumn 2007 (Fig. 3). In VJ, occupancy peaked at approximately $80 \%$ in autumn 2006 , when the crash phase commenced (i.e. 1 year before $\mathrm{KO}$ ). In IF, the region with lowest abundance and occupancy of tundra voles in the increase phase of the cycle, the peak was attained in summer 2007 with approximately $60 \%$ occupancy. Compared to the other two regions, $\mathrm{KO}$ appeared to exhibit the most consistent seasonal dynamics in the increase and peak of the cycle with distinct increases between summer and autumn and decreases between autumns and summers (Fig. 3). 
Fig. 4 Predicted probability of occurrence (occupancy) of tundra voles as a function of edge density (upper panels) and thicket height (lower panels) per season (summer and autumn), year (2005 and 2006) and region $(\mathrm{KO}, \mathrm{VJ}$ and IF). Note that the figure legend is identical for all four panels
Summer

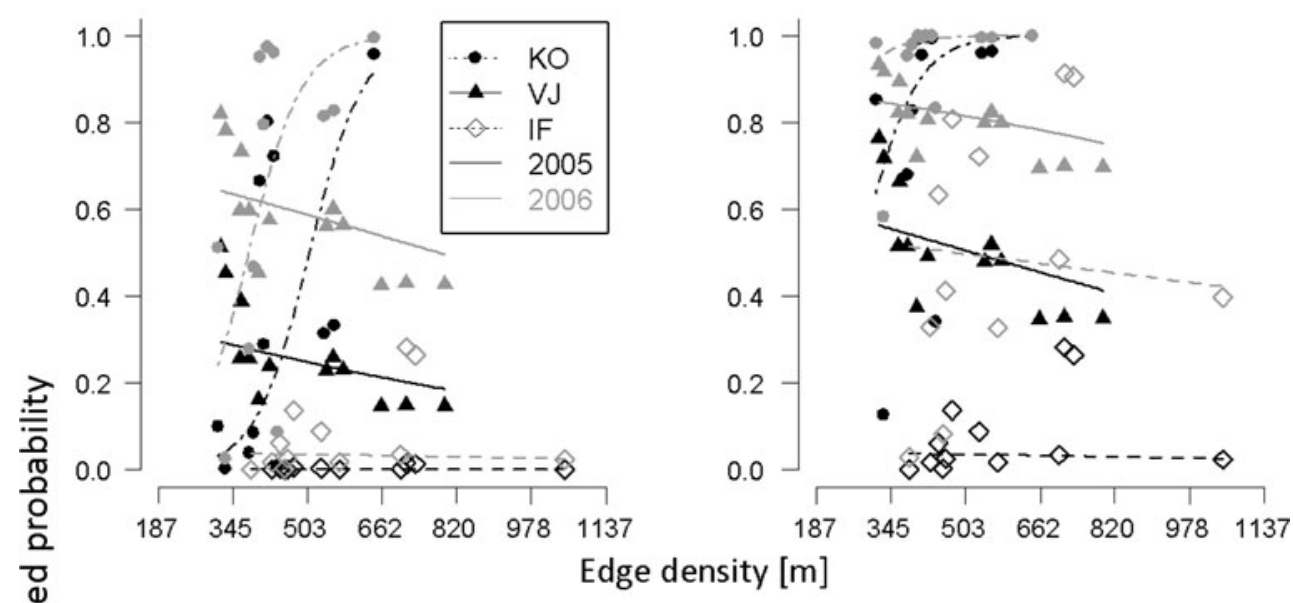

Autumn

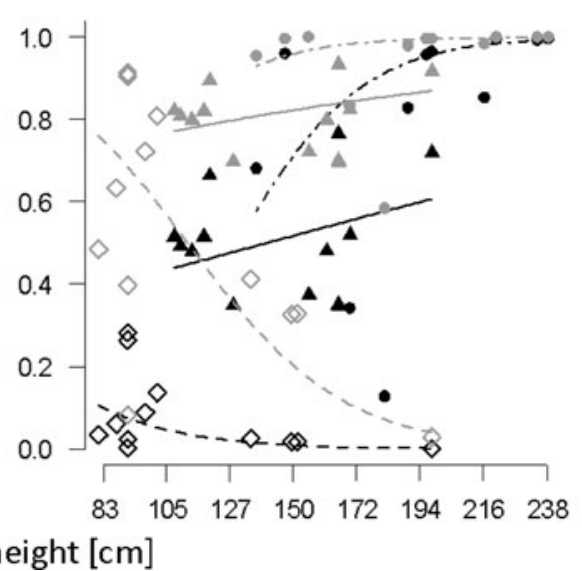

Effects of willow thicket configuration

Besides the terms that accounted for the region-specific dynamics (see above and Fig. 3), the best occupancy model for the increase phase of the cycle (years 2005 and 2006) included the two-way interaction between the four willow thicket variables and region (Tables S1 and S3, Appendix). The most influential of these two-way interactions was due to the effect of edge density and height of thickets on tundra vole occupancy in region KO (Fig. 4). Specifically, the probability of tundra vole occupancy increased steeply with density of thicket edges (estimate: $2.771,95 \%$ CI: [0.407, 6.002]) and height of thickets (estimate: 2.008, 95\% CI: $[0.539,3.996])$ in region $\mathrm{KO}$.

The best model for tundra vole abundance displayed a more complex structure than the occupancy models, with two-way interactions between the willow thicket variables and both region and year (Table S2 and S4, Appendix). However, none of the region- or year-specific slope estimates for thicket variables was statistically significant (Table S4, Appendix).

\section{Discussion}

In the present study, we employed a large-scale study design, which allowed us to demonstrate that tundra vole populations to some extent may become affected by changes in the configuration of willow thickets. However, the relations we found between thicket variables and tundra vole dynamics were not consistent. The configuration of willow thicket was only influential in terms of probability of patch occupancy and only in one of the three study regions in the increase phase of the multi-annual population cycle. Consequently, just as in previous studies conducted in a completely different setting (Ims and Andreassen 2000), region-specific factors appeared to be most influential to overall population dynamics, including to what extent local habitat features played any role. However, whether the regional influence was due to the action of predators (such as in the study of Ims and Andreassen (2000)) or whether some other mechanism responsible for the generation of cyclic dynamics was involved, cannot be determined based on the present analysis. 
Interestingly, the relation between willow thicket configuration and tundra vole dynamics was only prevalent in the region $\mathrm{KO}$, where tundra voles attained their highest occupancy and abundance. In this region, tundra vole occupancy increased with edge density and height of thickets. This was not an artifact of the higher number of voles caught in $\mathrm{KO}$, as the catch of tundra voles in $\mathrm{VJ}$ in 2006 exceeded the catch in KO in 2005. The positive effect of edge density was expected based on a previous study demonstrating that tundra voles prefer to forage in edge habitats (Hovland et al. 1999). Edge habitats may provide both food and cover, which are generally considered to be the most important components of habitat quality in Microtus voles (Tast 1966; Rose and Birney 1985). Why such food resource related to habitat features did not affect habitat occupancy of root voles in the two other regions is not clear. However, it is likely that some factors other than the habitat features examined in this study acted to limit the spatial distribution of tundra voles in the regions VJ and IF. Indeed, in these two study regions, the habitat occupancy never attained the levels they did in KO. Moreover, the consistent increase in occupancy and abundance over the plant growth season (i.e. between summer and autumn) witnessed both in the increase and peak phase of the cycle in region $\mathrm{KO}$ was not evident in VJ and IF. A general lesson from our demonstration of highly contrasting responses of tundra voles to willow thicket configuration between similar study regions is that results from spatially restricted studies of habitat effects on small mammals may have limited applicability. In fact, most habitat selection studies in small mammals are conducted on spatial scales that are much smaller than the individual regions included in our study.

It has been proposed that reindeer overbrowsing in Finnmark could have detrimental effect on the population levels on other tundra herbivores (Tømmeraas 1993; Kjellen and Roos 2000; Angerbjörn et al. 2001; Ratcliffe 2005). This could be mediated by a reduced extent or increased fragmentation/shredding of willow thickets or reduced height and density of thickets due to intense reindeer browsing in riparian habitats (Ims et al. 2007). Ravolainen (2009) found indications that reindeer imposed a habitat shredding effect on the willow thickets, while several authors have shown that reindeer reduce the height of thickets (Olofsson 2001; Pajunen et al. 2008; Olofsson et al. 2009; Kitti et al. 2009). On the other hand, climate warming is expected to increase the height (Forbes et al. 2010) as well as the extent (e.g. Sturm et al. 2001; Tape et al. 2006) of thickets. The lack of effects of willow configuration variables on tundra vole dynamics in two out of three riparian regions subject to the present study, and the specific effects of willow thicket shredding and height in one region, indicates that we do not have evidence for strong and consistent impacts of future climate or browsing induced changes of tundra shrubbiness on tundra voles.

Acknowledgments We are grateful to Knut Langeland for assistance on classification of willow thickets from aerial photographs, Phillip D. Mellison for assistance with extraction of willow configuration variables from FRAGSTAT and to Eeva Soininen, Virve $\mathrm{T}$. Ravolainen and the many field assistants for great leadership and stamina during field work. This study, which is a contribution from the "EcoFinn" project, was financed by the Norwegian Research council.

Open Access This article is distributed under the terms of the Creative Commons Attribution Noncommercial License which permits any noncommercial use, distribution, and reproduction in any medium, provided the original author(s) and source are credited.

\section{References}

Andreassen HP, Hertzberg K, Ims RA (1998) Space-use responses to habitat fragmentation and connectivity in the root vole Microtus oeconomus. Ecology 79:1223-1235

Angerbjörn A, Tannerfeldt M, Lundberg H (2001) Geographical and temporal patterns of lemming population dynamics in Fennoscandia. Ecography 24:298-308

Bates D, Maechler M, Dai B (2008) Lme4: Linear mixed-effects models using s4 classes (version 0.999375-20) [computer software]. Available at http://cran.R-project.Org/

Batzli GO, Henttonen H (1990) Demography and resource use by microtine rodents near Toolik lake, Alaska, USA. Arct Alp Res 22:51-64

Batzli GO, White RG, MacLean SF, Pitelka FA, Collier B (1980) The herbivore-based trophic system. In Brown J, Miller PC, Tieszen LL, Bunnell FL (eds) An arctic ecosystem: The coastal tundra at barrow. Dowden, Hutchinson, and Ross, Alaska, Stroudsburg (PA), pp 335-410

Bliss L (1997) Arctic ecosystems of North America. In: Wielgolaski FE (ed) Ecosystems of the world 3. Polar and Alpine Tundra. Elsevier, Amsterdam, pp 211-310

Bliss LC, Courtin GM, Pattie DL, Riewe RR, Whitfield DWA, Widden P (1973) Arctic tundra ecosystems. Annu Rev Ecol Syst 4:359-399

Bråthen KA, Ims RA, Yoccoz NG, Fauchald P, Tveraa T, Hausner VH (2007) Induced shift in ecosystem productivity? Extensive scale effects of abundant large herbivores. Ecosystems 10:773-789

Burnham KP, Anderson DR (2002) Model selection and multimodel inference: A practical information-theoretic approach, 2nd edn. Springer-Verlag, New York, USA

Chapin FS, Sturm M, Serreze MC, McFadden JP, Key JR, Lloyd AH, McGuire AD, Rupp TS, Lynch AH, Schimel JP, Beringer J, Chapman WL, Epstein HE, Euskirchen ES, Hinzman LD, Jia G, Ping CL, Tape KD, Thompson CDC, Walker DA, Welker JM (2005) Role of land-surface changes in Arctic summer warming. Science 310:657-660

den Herder M, Virtanen R, Roininen H (2004) Effects of reindeer browsing on tundra willow and its associated insect herbivores. J Appl Ecol 41:870-879

den Herder M, Virtanen R, Roininen H (2008) Reindeer herbivory reduces willow growth and grouse forage in a forest-tundra ecotone. Basic Appl Ecol 9:324-331

Ekerholm P, Oksanen L, Oksanen T (2001) Long-term dynamics of voles and lemmings at the timberline and above the willow limit as a test of hypotheses on trophic interactions. Ecography 24:555-568

Environmental Systems Research Institute (2002) Arcgis 9.1. ArcInfo, Redlands, California 
Forbes BC, Stammler F, Kumpula T, Meschtyb N, Pajunen A, Kaarlejarvi E (2009) High resilience in the Yamal-Nenets socialecological system, West Siberian Arctic, Russia. Proc Natl Acad Sci USA 106:22041-22048

Forbes BC, Fauria MM, Zetterberg P (2010) Russian Arctic warming and 'greening' are closely tracked by tundra shrub willows. Glob Chang Biol 16:1542-1554

Grass Development Team (2006) Geographic resources analysis support system (grass) [software]. Itc-irst. 6.1 edn., Trento, Italy

Hovland N, Andreassen HP, Ims RA (1999) Foraging behaviour of the root vole Microtus oeconomus in fragmented habitats. Oecologia 121:236-244

Ims RA, Andreassen HP (2000) Spatial synchronization of vole population dynamics by predatory birds. Nature 408:194-196

Ims RA, Rolstad J, Wegge P (1993) Predicting space use responses to habitat fragmentation - can voles Microtus oeconomus serve as an experimental-model system (ems) for capercaillie grouse Tetrao urogallus in boreal forest. Biol Conserv 63:261-268

Ims RA, Yoccoz NG, Bråthen KA, Fauchald P, Tveraa T, Hausner V (2007) Can reindeer overabundance cause a trophic cascade? Ecosystems 10:607-622

Johannesen E, Aars J, Andreassen HP, Ims RA (2003) A demographic analysis of vole population responses to fragmentation and destruction of habitat. Popul Ecol 45:47-58

Killengreen ST, Ims RA, Yoccoz NG, Bråthen KA, Henden J-A, Schott T (2007) Structural characteristics of a low Arctic tundra ecosystem and the retreat of the arctic fox. Biol Conserv 135:459472

Kitti H, Forbes B, Oksanen J (2009) Long- and short-term effects of reindeer grazing on tundra wetland vegetation. Pol Biol 32:253261

Kjellen N, Roos G (2000) Population trends in swedish raptors demonstrated by migration counts at Falsterbo, Sweden 1942-97. Bird Study 47:195-211

McGarigal K, Marks BJ (1995) Fragstat: Spatial pattern analysis program for quantifying landscape structure. General technical report pnw_gtr-351. US Department of Agriculture, Forest Service, USA

Meffe GK, Carroll CR (eds) (1994) Principles of conservation biology. Sinauer, Sunderland

Moen A (1999) Nasjonalatlas for Norge: Vegetasjon. Statens kartverk. Kart, Hønefoss, pp 69-92

Moen J, Danell O (2003) Reindeer in the Swedish mountains: An assessment of grazing impacts. Ambio 32:397-402

Myllymãki A, Paasikallio A, Pankakoski E, Kanervo V (1971) Removal experiments on small quadrats as a mean of rapid assessment of the abundance of small mammals. Ann Zool Fenn 8:177-185

Mysterud A, Ims RA (1998) Functional responses in habitat use: Availability influences relative use in trade-off situations. Ecology 79:1435-1441

Oksanen L, Oksanen T (1981) Lemmings (Lemmus lemmus) and greysided voles (Clethrionomys rufocanus) in interaction with their resources and predators on Finnmarksvidda, northern Norway. Reports from the Kevo Subarctic Research Station 17:7-31
Oksanen L, Virtanen R (1995) Topographic, altitudinal and regional patterns in continental and suboceanic heath vegetation of northern Fennoscandia. Acta Bot Fenn 153:1-80

Oksanen T, Oksanen L, Dahlgren J, Ofsson J (2008) Arctic lemmings, Lemmus spp. and Dicrostonyx spp.: Integrating ecological and evolutionary perspectives. Evol Ecol Res 10:415-434

Olofsson J (2001) Influence of herbivory and abiotic factors on the distribution of tall forbs along a productivity gradient: A transplantation experiment. Oikos 94:351-357

Olofsson J, Oksanen L, Callaghan T, Hulme PE, Oksanen T, Suominen O (2009) Herbivores inhibit climate-driven shrub expansion on the tundra. Glob Chang Biol 15:2681-2693

Pajunen A, Virtanen R, Roininen H (2008) The effects of reindeer grazing on the composition and species richness of vegetation in forest-tundra ecotone. Pol Biol 31:1233-1244

Pinheiro JC, Bates DM (2000) Mixed-effects models in S and S-plus. Springer, New York

R Development Core Team (2009) R: A language and environment for statistical computing. R Foundation for Statistical Computing, Vienna, Austria

Ratcliffe DA (2005) Lapland: A natural history. Poyser, London

Ravolainen VT (2009) Tundra plant diversity as influenced by biotic interactions. Dissertation. University of Troms $\varnothing$, Troms $\varnothing$

Rose RK, Birney EC (1985) Community ecology. In: Tamarin RT (ed) Biology of the new world Microtus, vol 8. Special Publication, Am Soc Mammal, pp 310-339

Stenseth NC, Lidicker WZ (1992) Animal dispersal: Small mammals as a model. Chapman \& Hall, London

Sturm M, Racine C, Tape K (2001) Climate change: Increasing shrub abundance in the Arctic. Nature 411:546-547

Sturm M, Schimel J, Michaelson G, Welker JM, Oberbauer SF, Liston GE, Fahnestock J, Romanovsky VE (2005) Winter biological processes could help convert Arctic tundra to shrubland. Bioscience 55:17-26

Tape K, Sturm M, Racine C (2006) The evidence for shrub expansion in northern Alaska and the Pan-Arctic. Glob Chang Biol 12:686702

Tast J (1966) The root vole Microtus oeconomus (Pallas) as an inhabitant of seasonally flooded land. Ann Zool Fenn 3:127-171

Tast J (1968) Influence of the root vole Microtus oeconomus (Pallas) upon the habitat selection of the field vole. Microtus agrestis (L.), in northern Finland. Ann Acad Sci Fenn 136:1-23

Tømmeraas P (1993) The status of gyrfalcon Falco rusticola research in northern Fennoscandia 1992. Fauna Nor Ser C Cinclus 16:75-82

Tveraa T, Fauchald P, Yoccoz NG, Ims RA, Aanes R, Høgda KA (2007) What regulate and limit reindeer populations in Norway? Oikos 116:706-715

Walker DA, Raynolds MK, Daniels FJA, Einarsson E, Elvebakk A, Gould WA, Katenin AE, Kholod SS, Markon CJ, Melnikov ES, Moskalenko NG, Talbot SS, Yurtsev BA, Team C (2005) The Circumpolar Arctic vegetation map. J Veg Sci 16:267-282

Yoccoz NG, Ims RA (2004) Spatial population dynamics of small mammals: Some methodological and practical issues. Anim Biodivers Conserv 27:427-435 